\title{
KESAKSIAN DALAM PERSPEKTIF HUKUM ISLAM
}

\author{
Oleh \\ Arbanur Rasyid \\ Dosen Fakultas Syariah dan Ilmu Hukum IAIN Padangsidimpuan \\ Email: arbanurrasyid@iain-padangsidimpuan.ac.id
}

\begin{abstract}
Abstrac
Tulisan ini mendeskripsikan seputar kesaksian dalam perspektif hukum Islam, disini yang menjadi fokus pembahasan dalam tulisan ini adalah mengenai seluk beluk kesaksian dalam kacamata hukum Islam tentang bagaimana hukum Islam mengatur seputar kesaksian dan apa perbedaan hukum Islam dengan hukum lainnya dalam mengatur kesaksian. Untuk menjawab permaslahan ini, penulis menggunakan metode studi pustaka dengan menelusuri literatur-literatur yang membahas mengenai kesaksian terutama kitab-kitab fikih klasik.

Temuan dalam penelusuran itu, bahwa hukum Islam memiliki persamaan dan perbedaan di bidang kesaksian. Salah satu perbedaan itu bahwa di dalam hukum Islam memberikan syarat terhadap orang saksi haruslah adil. Maksud adil di sini tidak hanya bermakna menyampaikan apa adanya tanpa menambah-nambahi atau mengurang-ngurangi tetapi termasuk menjadi insan yang taat kepada Allah SWT, maka orang yang sering melakukan dosa dianggap tidak adil sehingga tidak dibolehkan menjadi saksi.
\end{abstract}

Kata Kunci; Kesaksian, Perspektif, Hukum, dan Islam

\section{A. Pendahuluan}

Belakangan ini, rakyat Indonesia sudah menikmati transparansi hukum melalui siaran langsung persidangan Mahkamah Konstitusi (MK) perihal pilpres, semua masyarakat Indonesia menikmati linimasa tersebut di laman sosial media. Transparansi tersebut menuai berbagai respon warganet, bahkan sebagaian warganet mengangapa saksi-saksi yang dihadirkan sebagai komedi belaka dan tidak sedikit pula dari mereka yang meragukan kualitas kesaksian dari para saksi. Beranjak dari sini, penulis mencoba menganalisa bagaimanakah perspektif syariat dalam menyikapi kesaksian yang akan kupas dalam pembahasan selanjutnya. 


\section{B. Pengertian Kesaksian}

Kata saksi dalam bahasa Arab adalah syahadah yang berasal dari kata musyaahadah $^{1}$ yang berarti melihat dengan mata karena orang yang menjadi syahid (orang yang menyaksikan) itu memberitahukan tentang apa yang disaksikan dan yang dilihatnya. Maknanya, dalam kesaksian menggunakan kata asyhadu (aku menyaksikan) atau syahidtu (aku telah menyaksikan).

Selain itu kata syahadah, menurut sebagaian pakar bahasa Arab bersal dari kata i'laam yang berarti pemberitahuan sebagaimana terdapat al-Qur'an pada surah Ali Imran ayat 18 yang berbunyi sebagai berikut :

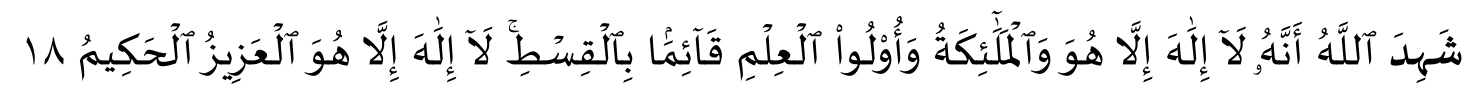
Artinya:

"Allah SWT menyatakan bahwasanya tidak ada Tuhan melainkan Dia (yang berhak disembah), Yang menegakkan keadilan. Para malaikat dan orang-orang yang berilmu (juga menyatakan yang demikian itu). Tiidak ada Tuhan melainkan Dia (yang berhak disembah), Yang Maha Perkasa lagi Maha Bijaksana". \{Qs. Ali Imran/2:18\}

Ayat ini memberikan gambaran bahwa kata syahida bermakna 'alima (mengetahui) karena secara tidak langsung seorang saksi menyaksikan atau menyampaikan sesuatu yang diketahuinya $^{2}$ melalui pancaindra penglihatan atau pendengaran sedangkan orang lain tidak mengetahui hal itu. Maka dalam ajaran Islam, bahwa tidak boleh bagi seseorang memberikan kesaksian yang diketahuinya. Karena kesaksian itu sebagai pengetahuan maka para pakar mendefenisikan kesaksian yang antara lain sebagai berikut :

1. Menurut Muhammad Salam Madzkur : ${ }^{3}$

Artinya:

$$
\text { الشهَادَةُ عِبَارَ صِدْقِ فِيْ مَجْلِسِ الحُكْمِ بِلَفْظِ الشهَادَةِ لإِثْبَاتِ حَق عَلَى الْغَيْرِ }
$$

"Kesaksian adalah mengenai pemberitahuan seseorang yang benar di depan pengadilan dengan ucapan kesaksian untuk menetapkan suatu hak terhadap orang lain”.

2. Menurut Ibn al-Human : ${ }^{4}$

$$
\text { إخخبَارَ صِدْقِ لإِثْبَاتِ حَقق بِلَفْظِ الشهَادَةِ فِى مَجْلِسِِ القضَاءِ }
$$

Artinya:

"Pemberitahuan yang benar untuk menetapkan suatu hak dengan ucapan kesaksian di depan siding pengadilan".

3. Menurut Mahalli : ${ }^{5}$

إِخْبَارِ بِحَق لِلْغَيْرِ عَلَى الْغَيْرِ بِلَفْظةٍ أَشْهَد 
Artinya:

"Bahwasanya kesaksian itu adalah memberitahukan dengan sebenarnya hak seseorang terhadap orang lain dengan lafazh aku bersaksi.

Seorang saksi seyogianya adalah orang-orang yang menyaksikan secara langsung dengan mata kepala sendiri terhadap suatu peristiwa bukan orang-orang yang hanya mendengar dari orang lain karena akan menimbulkan syubhat (keraguan) sehingga imam Abu Hanifah berpendapat bahwa tidak boleh menerima kesaksian orang buta. Berbeda halnya dengan imam Malik dan Ahmad yang berpendapat bahwa boleh menerima kesaksian orang buta lewat pendengarannya terutama dalam beberapa kasus yaitu mengenahi pernikahan, talak, jual-beli, pinjam-meminjam, dan wakaf.

\section{Urgensi Kesaksian}

Seorang saksi menempati posisi yang urgen (amat penting) dalam memvalidasi suatu peristiwa atau kasus hukum di pengadilan, keterangan saksi juga berfungsi sebagai upaya menetapkan hak-hak seorang insan manusia. Karena dengan adanya kesaksian sangat membantu seorang hakim dalam menetapkan hak dan memutuskan hukuman kepada seorang atau memutuskan tidak bersalah terhadap orang yang dituduh dan difitnah telah melakukan suatu kejahatan.

Pada umumnya, sebuah kasus sulit dituntaskan tanpa ada kesaksian dari lisan seorang saksi. Bahkan menurut Ibnu Hazm, sebuah keputusan akan batal apabila seorang saksi menarik kembali kesaksiaannya baik sesudah diputuskan apalagi sebelum diputuskan. ${ }^{6}$ Kesaksian tiadak hanya ada di pengadilan anamun hampir disetiap aktivitas kehidupan insan manusia membutuhkan kesaksian, termasuk aktivitas yang terdapa di rumah sendiri seperti wasiat orang yang mau meninggal perlu dipersaksikan sebagaimana dijelaskan Allah SWT dalan al-Qur'an pada surah al-Maidah ayat 106 yang berbunyi sebagai berikut :

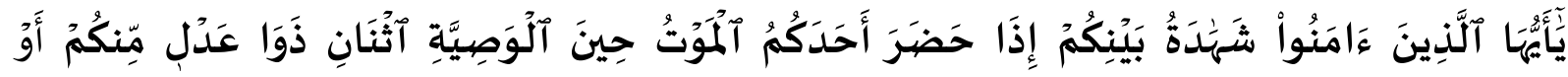

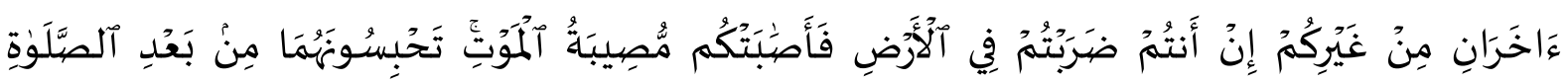

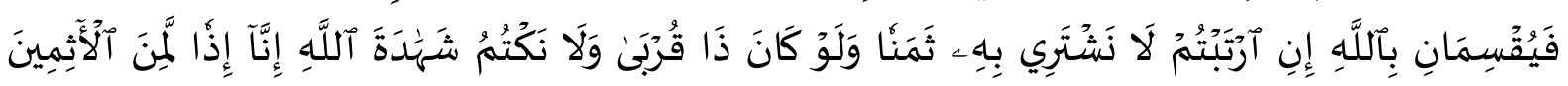

Artinya:

"Hai orang-orang yang beriman, apabila salah seorang kamu menghadapi kematian, sedang dia akan berwasiat, maka hendaklah (wasiat itu) disaksikan oleh dua orang yang adil di antara kamu, atau dua orang yang berlainan agama dengan kamu, apabila kamu dalam perjalanan dimuka bumi lalu kamu ditimpa bahaya kematian. Kamu tahan kedua saksi itu sesudah sembahyang (untuk bersumpah), lalu mereka keduanya bersumpah dengan 
nama Allah SWT, jika kamu ragu-ragu: "(Demi Allah SWT) kami tidak akan membeli dengan sumpah ini harga yang sedikit (untuk kepentingan seseorang), walaupun dia karib kerabat, dan tidak (pula) kami menyembunyikan persaksian Allah SWT; sesungguhnya kami kalau demikian tentulah termasuk orang-orang yang berdosa" $\{$ Qs. al-Maidah/5: 106\}

Tidak hanya pada persoalan wasiat, dalam hal segala bentuk transaksi juga dalam Islam dianjurkan untuk menghadirkan saksi sebagaimana dijelaskan Allah SWT dalam al-Qur'an pada surah an-Nisa ayat 6 yang berbunyi sebagai berikut :

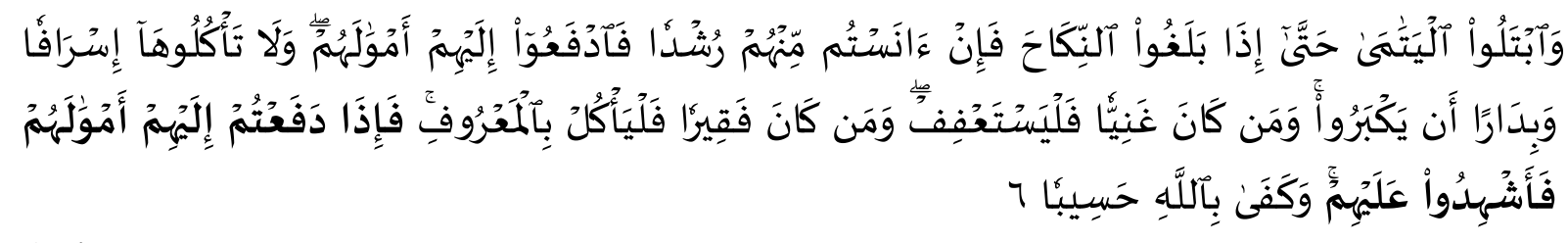

Artinya:

"Dan ujilah anak yatim itu sampai mereka cukup umur untuk kawin. Kemudian jika menurut pendapatmu mereka telah cerdas (pandai memelihara harta), maka serahkanlah kepada mereka harta-hartanya. Dan janganlah kamu makan harta anak yatim lebih dari batas kepatutan dan (janganlah kamu) tergesa-gesa (membelanjakannya) sebelum mereka dewasa. Barang siapa (di antara pemelihara itu) mampu, maka hendaklah ia menahan diri (dari memakan harta anak yatim itu) dan barangsiapa yang miskin, maka bolehlah ia makan harta itu menurut yang patut. Kemudian apabila kamu menyerahkan harta kepada mereka, maka hendaklah kamu adakan saksi-saksi (tentang penyerahan itu) bagi mereka. Dan cukuplah Allah SWT sebagai Pengawas (atas persaksian itu)”. \{Qs. an-Nisa/4:6\}

Bahkan di pengadilan, keterangan saksi diposisikan diurutan pertama dibandingkan dengan alat bukti lainnya sehingga alat bukti yang pertama kali diperiksa dalam tahap pembuktian di persidangan adalah keterangan saksi, dan banyak kasus-kasus yang tidak dapat diungkap (tidak terselesaikan) dikarenakan tidak dapat menghadirkan saksi di persidangan. Sebab, kesaksian atau keterangan saksi adalah merupakan salah satu alat bukti yang sah dalam proses peradilan karena ia melihat langsung, mendengar langsung, atau mengalami sendiri terjadinya suatu pristiwa hukum. Berbicara mengenai kesaksian maka sesungguhnya pada hakikatnya adalah membicarakan masalah penegakan hukum di pengadilan.

\section{Hukum Memberikan Kesaksian}

Pentingnya sebuah kesaksian, maka para ulama mengkategorikannya sebagai fardhu 'ain (kewajiban person atau perorangan) bagi orang-orang yang dipanggil untuk memberikan keterangan mengenai suatu kasus dengan sebenarnya agar kebenaran terungkap, sekalipun tidak dipanggil namun tetap wajib memberikan kesaksian untuk menegakkan kebenaran sebagaimana firman Allah SWT dalam al-Qur'an pada surah al-Baqarah ayat 282 dan 283 yang berbunyi sebagai berikut : 


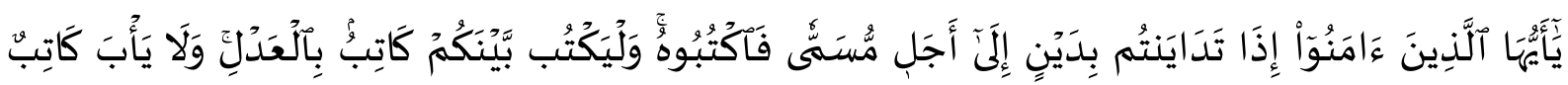

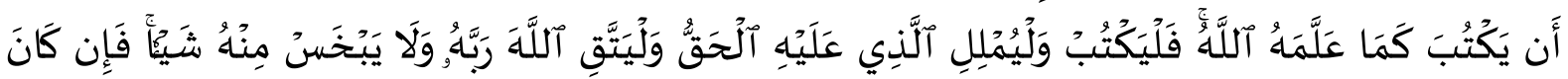

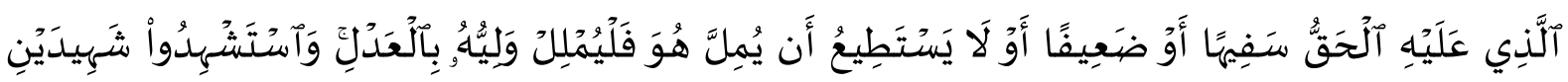

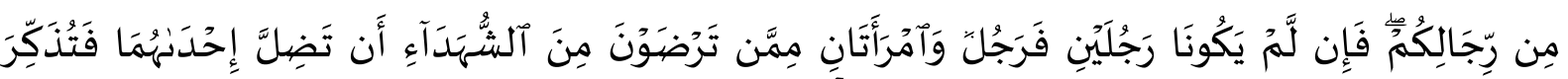

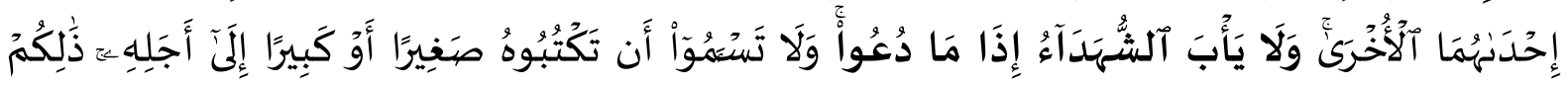

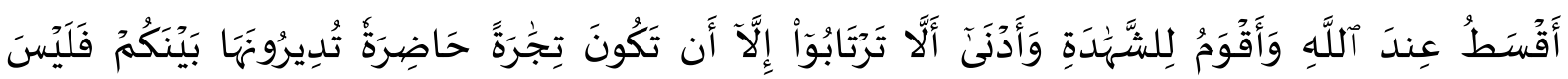

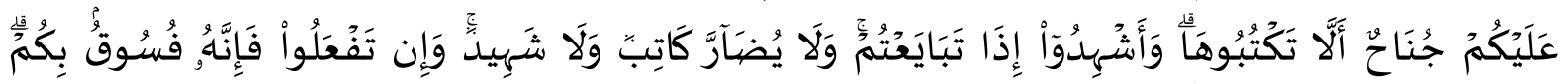

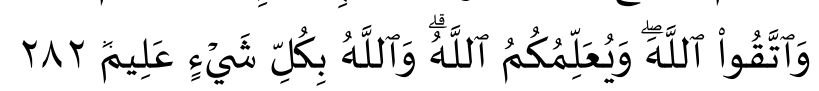

Artinya:

"Hai orang-orang yang beriman, apabila kamu bermu'amalah tidak secara tunai untuk waktu yang ditentukan, hendaklah kamu menuliskannya. Dan hendaklah seorang penulis di antara kamu menuliskannya dengan benar. Dan janganlah penulis enggan menuliskannya sebagaimana Allah SWT mengajarkannya, meka hendaklah ia menulis, dan hendaklah orang yang berhutang itu mengimlakkan (apa yang akan ditulis itu), dan hendaklah ia bertakwa kepada Allah SWT Tuhannya, dan janganlah ia mengurangi sedikitpun daripada hutangnya. Jika yang berhutang itu orang yang lemah akalnya atau lemah (keadaannya) atau dia sendiri tidak mampu mengimlakkan, maka hendaklah walinya mengimlakkan dengan jujur. Dan persaksikanlah dengan dua orang saksi dari orang-orang lelaki (di antaramu). Jika tak ada dua oang lelaki, maka (boleh) seorang lelaki dan dua orang perempuan dari saksi-saksi yang kamu ridhai, supaya jika seorang lupa maka yang seorang mengingatkannya. Janganlah saksi-saksi itu enggan (memberi keterangan) apabila mereka dipanggil; dan janganlah kamu jemu menulis hutang itu, baik kecil maupun besar sampai batas waktu membayarnya. Yang demikian itu, lebih adil di sisi Allah dan lebih menguatkan persaksian dan lebih dekat kepada tidak (menimbulkan) keraguanmu. (Tulislah mu'amalahmu itu), kecuali jika mu'amalah itu perdagangan tunai yang kamu jalankan di antara kamu, maka tidak ada dosa bagi kamu, (jika) kamu tidak menulisnya. Dan persaksikanlah apabila kamu berjual beli; dan janganlah penulis dan saksi saling sulit menyulitkan. Jika kamu lakukan (yang demikian), maka sesungguhnya hal itu adalah suatu kefasikan pada dirimu. Dan bertakwalah kepada Allah SWT; Allah SWT mengajarmu; dan Allah SWT Maha Mengetahui segala sesuatu". \{Qs. al-Baqarah/2:282\}

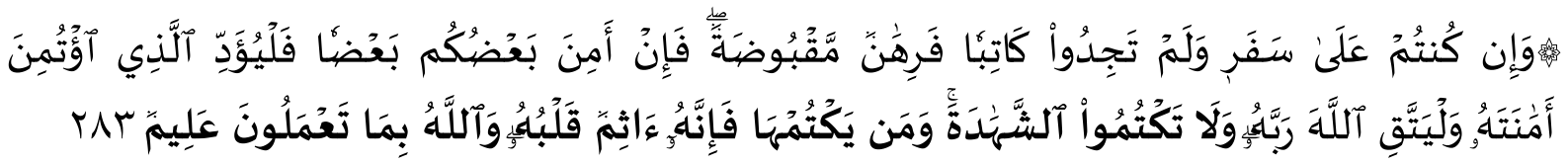
Artinya:

“ Jika kamu dalam perjalanan (dan bermuamalah tidak secara tunai) sedang kamu tidak memperoleh seorang penulis, maka hendaklah ada barang tanggungan yang dipegang (oleh yang berpiutang). Akan tetapi jika sebagian kamu mempercayai sebagian yang lain, maka hendaklah yang dipercayai itu menunaikan amanatnya (hutangnya) dan hendaklah ia bertakwa kepada Allah SWT Tuhannya; dan janganlah kamu (para saksi) menyembunyikan persaksian. Dan barangsiapa yang menyembunyikannya, maka sesungguhnya ia adalah orang yang berdosa hatinya; dan Allah SWT Maha Mengetahui apa yang kamu kerjakan”. \{Qs. al-Baqarah/2:283 \} 
Selain ayat di atas, Rasulullah SAW juga pernah bersabda :

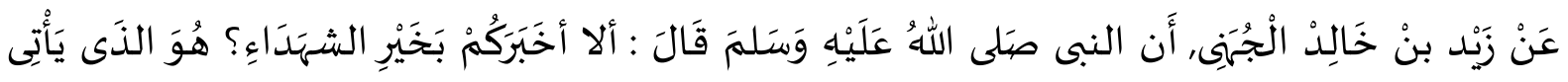

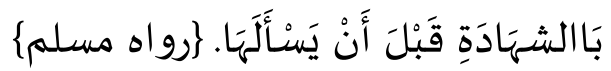

Artinya:

"Dari Zayd bin Khalid al-Juhani, bahwasanya Nabi Muhammad SAW bersabda : "Apakah tidak ku kabarkan kepada kamu tentang sebaik-baik saksi? Ialah orang yang memberikan kesaksiannya sebelum ia diminta untuk mengemukakannya”. $\{\text { HR. Muslim }\}^{7}$

Hadis ini menunjukkan, bahwa untuk memberikan kesaksian tidak mesti dipanggil baru memberikan kesaksian namun harus aktif dalam rangka memberikan kesaksian terhadap suatu kasus hukum. Bahkan lebih dari itu, memberikan kesaksian tidak hanya sebatas kewajiban tetapi untuk menegakkan kebenaran dan menolak kezaliman serta secara tidak langsung dengan kesaksian yang telah disampaikan sudah termasuk menolong orang-orang yang terlibat dalam persoalan hukum tersebut sehingga jelas siapa yang dirugikan dari peristiwa tersebut sehingga hakim dapat memberikan putusan sesuai dengan yang seharusnya. Karena memberikan kesaksian adalah merupakan kebaikkan maka sudah sepatutnya diungkapkan dengan sebenar-benarnya dan diucapkan dengan niat semata-mata karena Allah SWT sebagaimana ditegaskan Allah SWT dalam surah an-Nisa ayat 135 dan surah ath-Talak ayat 2 yang berbunyi sebagai berikut :

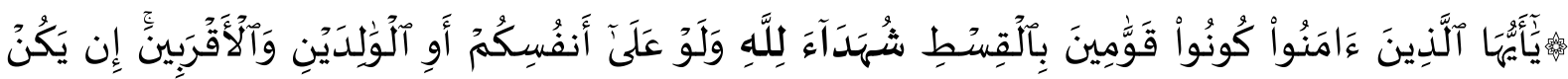

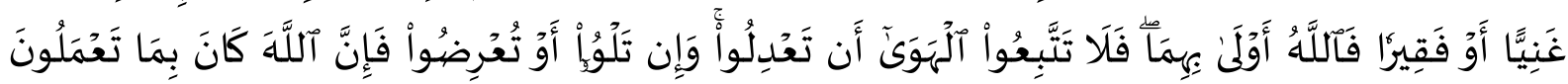

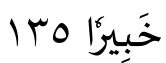

Artinya:

"Wahai orang-orang yang beriman, jadilah kamu orang yang benar-benar penegak keadilan, menjadi saksi karena Allah SWT biarpun terhadap dirimu sendiri atau ibu bapa dan kaum kerabatmu. Jika ia kaya ataupun miskin, maka Allah SWT lebih tahu kemaslahatannya. Maka janganlah kamu mengikuti hawa nafsu karena ingin menyimpang dari kebenaran. Dan apabila kamu memutar balikkan (kata-kata) atau enggan menjadi saksi, maka sesungguhnya Allah SWT adalah Maha Mengetahui segala apa yang kamu kerjakan”. \{Qs. an-Nisa/4:135\}

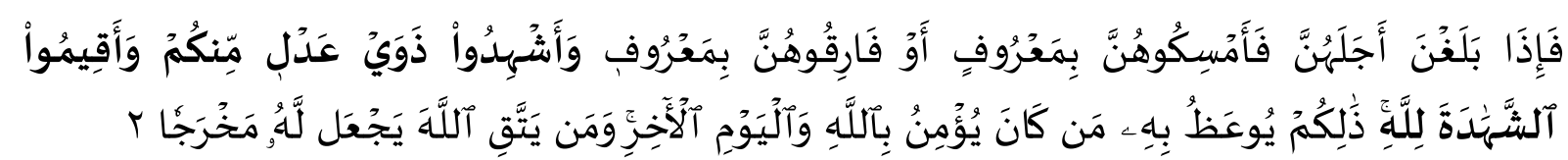
Artinya:

"Apabila mereka telah mendekati akhir iddahnya, maka rujukilah mereka dengan baik atau lepaskanlah mereka dengan baik dan persaksikanlah dengan dua orang saksi yang adil di antara kamu dan hendaklah kamu tegakkan kesaksian itu karena Allah. Demikianlah diberi pengajaran dengan itu orang yang beriman kepada Allah dan hari akhirat. Barangsiapa bertakwa kepada Allah niscaya Dia akan mengadakan baginya jalan keluar". \{Qs. AthThalak/65: 2 \} 
Kewajiban untuk memberikan kesaksian disini, menurut para ulama apabila tidak ada bahaya yang mengahadangnya untuk memberikan kesaksian baik dari ancaman terhadap badannya, kehormatannya, hartanya, ataupun keluarganya. Terutama ancaman yang menuntut supaya memberikan kesaksian palsu dengan memutar balikkan fakta sehingga membuat seorang terzolimi. Memberikan kesaksian palsu sama saja dengan menipu, ${ }^{8}$ maka dalam pandangan Islam tindakan bersaksi palsu ini sangat dikecam Rasulullah SAW sebab prilaku ini merupakan bagaian dari dosa besar, karena membuat seseorang yang tidak bersalah menjadi bersalah dan yang bersalah menajdi bebas tidak bersalah sebagaimana sabda Rasulullah SAW sebagai berikut :

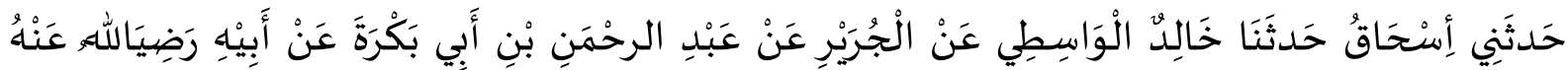

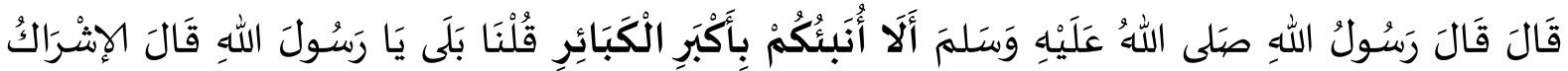

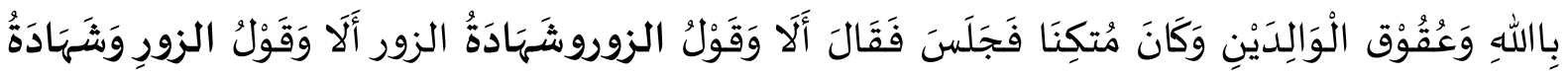

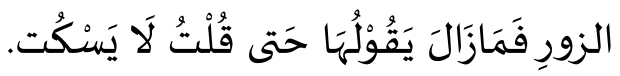

Artinya:

"Telah bercerita kepadaku Ishak mencertakan kepada kami Khalid al-Wasithi dari al-Jurairi dari Abdurrahman bin Abu Bakrah dari Ayahnya ra dia berkata bahwa Rasulullah SAW bersabda: "Tidak maukah aku beritahukan kepada kalian sesuatu yang termasuk dari dosa besar? Kami menjawab; "Tentu wahai Rasulullah SAW." Beliau bersabda: "Menyekutukan Allah SWT dan mendurhakai kedua orang tua." -ketika itu beliau tengah bersandar, kemudian duduk lalu melanjutkan sabdanya: "Perkataan dusta dan kesaksian palsu, perkataan dusta dan kesaksian palsu." Beliau terus saja mengulanginya hingga saya mengira beliau tidak akan berhenti." \{HR Bukhari\}

Dalam hadis di atas, menjelaskan bahwa konsekwensi prilaku bersaksi palsu setara musyrik (menyekutukan Allah SWT) karena al-Qur'an menjunjung tinggi kebenaran dan keadilan. Bahkan dalam surah an-Nisa ayat 135 dan surah al-Maidah ayat 8 yang meneegaskan bahwa seorang Mukmin yang takwa harus senantiasa bersikap adil meskipun akan memberatkan kerabat sendiri. Labih dari itu, al-Qur'an pada surah al-Furqan ayat 68-72 sudah menjelaskan seputar siksaan bagi orang-orang yang musyrik termasuk didalamnya pelaku saksi palsu.

\section{E. Syarat-Syarat Menjadi Saksi}

Saksi memiliki peranan penting dalam menetapkan seseorang bersalah atau tidak pada suatu peristiwa hukum, maka dalam Islam untuk memilih seorang saksi dipilih secara selektif 
guna mendapatkan informasi yang akurat. Menurut para ulama ada beberapa persyaratan bagi seorang saksi yang antara lain sebagai berikut :

1. Beragama Islam, menurut Mahalli bahwa seharusnya para saksi terdiri dari kaum Muslimin bukan dari kalangan non Muslim terutama terhadap suatu pristiwa hukum yang terjadi antara sesama umat Islam. ${ }^{1}$ Bahkan seyogianya para saksi terdiri dari orangorang Muslim yang beriman tingkat tinggi jangan orang Muslim yang berstatus Islam KTP (fasik atau kurang mengamalkan ajaran-ajaran Islam), maka apabila tidak ada yang lain disini perlu ketelitian sebagaimana diamanahkan Allah SWT dalam al-Qura'n yang berbunyi sebagai berikut :

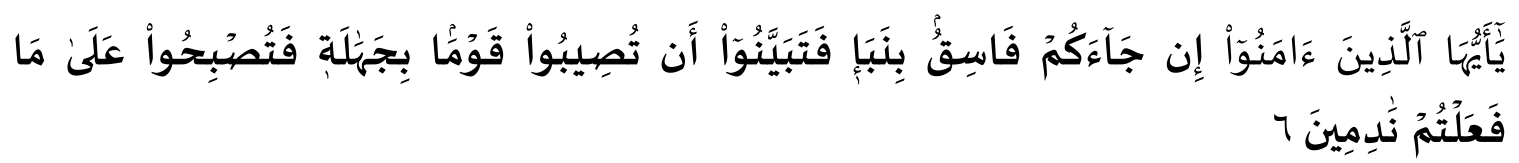

Artinya:

"Hai orang-orang yang beriman, apabila datang kepadamu orang fasik membawa suatu berita, maka periksalah dengan teliti agar kamu tidak menimpakan suatu musibah kepada suatu kaum tanpa mengetahui keadaannya yang menyebabkan kamu menyesal atas perbuatanmu itu". \{Qs. al-Hujarat/ 49:6 $\}$

Bahkan dalam ayat lain, ditegaskan bahwa orang-orang fasik tidak diperblehkan menjadi saksi sebagaimana diuraikan dalam surah an-Nur ayat 4 yang berbunyi sebagai berikut :

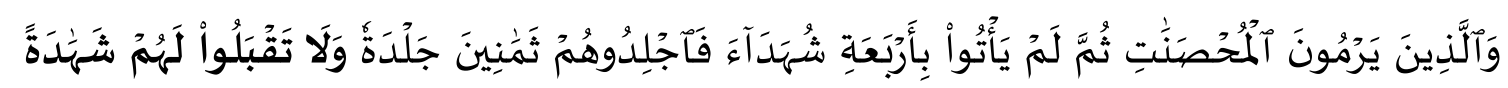

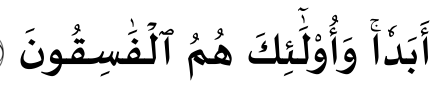

Artinya:;

"Dan orang-orang yang menuduh wanita-wanita yang baik-baik (berbuat zina) dan mereka tidak mendatangkan empat orang saksi, maka deralah mereka (yang menuduh itu) delapan puluh kali dera, dan janganlah kamu terima kesaksian mereka buat selama-lamanya. Dan mereka itulah orang-orang yang fasik". $\{$ Qs. an-Nur/24:4 $\}$

2. Bersifat adil, termasuk memberitahukan secara apa adanya dengan apa yang dilihatnya terhadap objek pristiwa hukum tersebut tanpa menambahi dan menguranginya, maka menurut Ibnu Hazm bahwa tidak boleh diterima kesaksian seorang laki-laki maupun perempuan yang tidak adil. ${ }^{9}$ Perintah untuk memberikan kesaksian dengan seadil-adilnya ini telah ditegaskan Allah SWT dalam al-Qur'an pada surah al-Maidah ayat 8 yang berbunyi sebagai berikut :

${ }^{1}$ Mahalli, Qalyubi wa 'Umairah, juz IV, ( Riyad : Maktabah ar-Riyaḍ li al-Hadiț̣ah, th ), hlm. 323. 


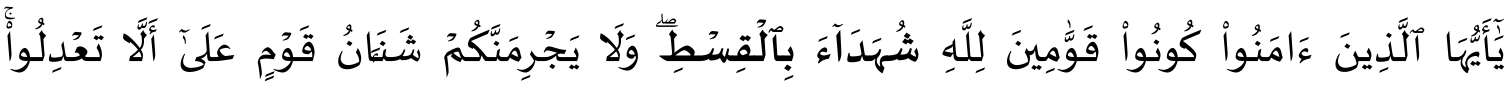

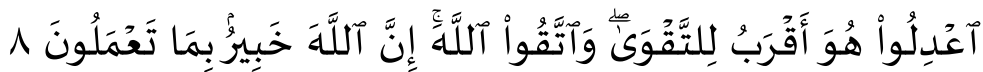

Artinya:

"Hai orang-orang yang beriman hendaklah kamu jadi orang-orang yang selalu menegakkan (kebenaran) karena Allah SWT, menjadi saksi dengan adil. Dan janganlah sekali-kali kebencianmu terhadap sesuatu kaum, mendorong kamu untuk berlaku tidak adil. Berlaku adillah, karena adil itu lebih dekat kepada takwa. Dan bertakwalah kepada Allah, sesungguhnya Allah Maha Mengetahui apa yang kamu kerjakan”. \{Qs. alMaidah/5:8\}

Seorang saksi harus bisa adil memberikan kesaksian, tidak boleh berpihak dan tidak boleh memberikan kesaksian atas dasar kebencian dan permusuhan maka dalam hukum Islam tidak diperbolehkan seseorang menjadi saksi terhadap perkara lawannya dikarenakan rasa kebencian dapat mempengaruhi sisi negatif dalam dirinya sebagaimana ditegaskan Rasulullah SAW sebagai berikut :

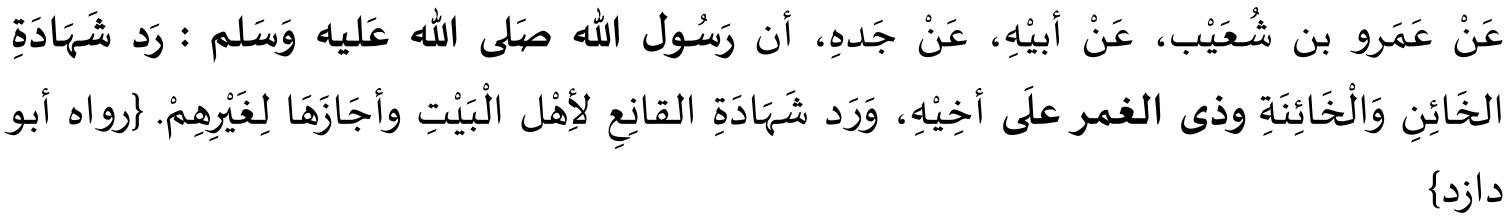

Artinya:

"Dari Amar bin Syua'ib dari ayahnya dari kakeknya, bahwa ia berkata : Rasulullah SAW menolak kesaksian pengkhianatan laki-laki dan perempuan, dan orang yang mempunyai permusuhan terhadap saudaranya dan menolak kesaksian pembantu rumah tangga terhadap tuannya dan membolehkan selainnya". \{HR. Abu Dawud\}

Larangan menjadi saksi terhadap orang yang ada permusuhan dengan orang yang berperkara karena dapat mempengaruhi dirinya berkata lain dalam mengemukakan kesaksian untuk menjatuhkan musuhnya. Selain itu, tidak hanya permusuhan saja yang dapat membuat seseorang tidak netral dalam mengemukakan kesaksian termasuk hubungan kekerabatan seperti kesaksian orangtua terhadap anaknya atau suami terhadap isterinya.

3. Balig dan berakal, para ulama fikih berpendapat bahwa salah satu dari orang-orang yang bebas dari hukum adalah anak-anak dan orang gila termasuk kesaksian mereka ditolak sebab menurut al-Jauhari dikarenakan tentang kesaksian berkaitan herat dengan tanggungjawab :

Artinya:

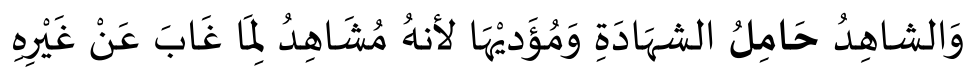


"Saksi ialah orang yang mempertanggungjawabkan kesaksian dan mengemukakannya, karena dia menyaksikan suatu (peristiwa) yang orang lain tidak menyaksikannya". ${ }^{10}$

Anak-anak dan orang gila tidak dapat diberikan taklif (memikul tanggungjawab) karena belum sempurna akal dalam memahami sesuatu, maka dalam Islam seorang saksi haruslah baliq dan berakal sehat sebab ia harus bisa menanggungjawabi setiap kesaksian yang disampaikannya. Namun, apabila seorang saksi yang semula sehat akal lalu setelah beberapa hari memberikan kesaksian tersebut dia menjadi gila maka kesaksiannya tetap diterima serta tidak boleh ditolak.

Mayoritas ulama menolak kesaksian anak-anak, namun apabila tidak ada orang baliq (dewasa) yang melihat suatu pristiwa hukum pada saat terjadi perkara tragedi tersebut kecuali anak-anak, seperti kasus-kasus yang berkaitan dengan anak-anak maka dalam hal ini menurut imam Hambali anak-anak pun diperbolehkan menjadi saksi atas perkara tersebut. Namun menurut imam Malik, bahwa kesaksian anak-anak disini bukanlah merupakan bertindak sebagai saksi melainkan hanya sebatas qarinah (petunjuk) saja karena sudah sangat jelas dalam sebuah hadis Rasulullah SAW bahwa anak-anak bebas dari pertanggungjawaban sebagaimana sabda Rasulullah SAW yang berbunyi sebagai berikut :

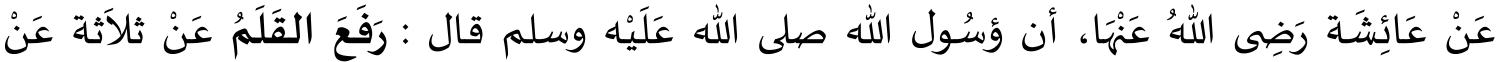

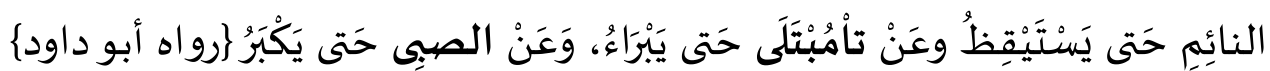

Artinya:

"Dari Aisyah r.a. Nabi Muhammad SAW bersabda : 'Bebas dari hukum terhadap tiga orang, yaitu : Orang yang tidur sampai dia bangun, orang gila sehingga ia berakal atau sadar dan anak-anak sampai ia dewasa". \{HR. Abu Daud\}

4. Memiliki kecakapan, seorang saksi seharusnya dari orang-orang yang dapat berbicara untuk menyampaikan dan menerangkan apa yang telah disaksikannya kepada hakim maka menurut Louis Ma'luf bahwa seorang saksi hendaknya memiliki kecakapan : ${ }^{11}$

Artinya:

$$
\text { أَلَذذِيْ يَحْبَرَهُ بِمَا شِهَدَهُ الْمَلَكَكُ اللسَـانِ }
$$

"Orang yang memberitahukan tentang apa yang telah di saksikannya yang mempunyai kemampuan bahasa".

Keccakapan dalam berbicara merupakan hal yang sangat penting untuk bertindak sebagai saksi, namun di era modern ini sebagian ulama membolehkan menerima kesaksian orang bisu dengan bahasa isyaratnya sebab di zaman sekarang sudah banyak ahli bahsa 
bidang dialog dengan orang bisu apalagi yang menjadi saksi tersebut pandai menuliskannya dengan tangannya sendiri sehingga dapat dipahami kesaksiannya.

Beranjak dari persyaratan di atas, dalam hukum Islam jumlah saksi pada masing pristiwa hukum berbeda seperti kasus perzinaan membutuhkan 4 (empat) orang saksi sebagaimana ditegaskan Allah SWT dalam al-Qur'an pada surah an-Nur ayat 13 yang berbunyi sebagai berikut :

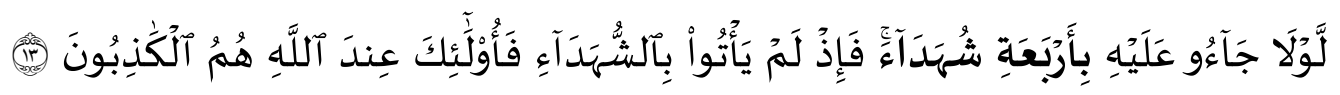

Artinya:

"Mengapa mereka (yang menuduh itu) tidak mendatangkan empat orang saksi atas berita bohong itu? Olah karena mereka tidak mendatangkan saksi-saksi maka mereka itulah pada sisi Allah orang-orang yang dusta”. \{Qs. an-Nur/24:13\}

Selain ayat di atas, dalam sebuah hadis juga ada terdapat mengenai jumlah saksi kasus perzinaan bahkan dijelaskan 4 (empat) saksi yang dimaksdu adalah laki-laki sebagaimana dalam hadsi Rasulullah SAW sebagai berikut :

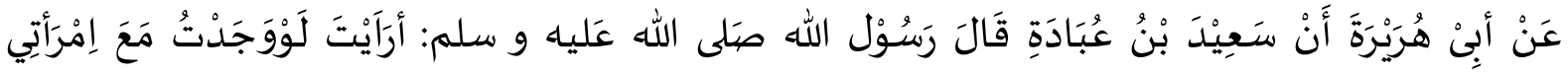

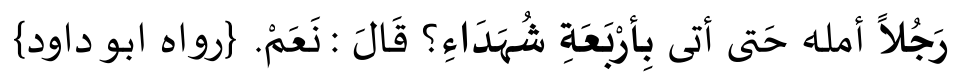

Artinya:

"Dari Abi Hurairah bahwasanya Sa'id bin 'Ubadah berkata kepada Rasulullah SAW 'Sependapatkah engkau andai aku mendapati laki-laki lain bersama isteriku lalu kutunda dahulu menuduh isteriku berbuat zina sampai aku mendatangkan empat orang saksi lakilaki?’ Nabi Muhammad SAW menjawab ‘ya'!.” \{HR. Abu Daud $\}^{12}$

Sedangkan kesaksian terhadap perkara kejahatan lainnya termasuk kejahatan hudud (jenis kejahatan yang ditetapkan Allah SWT dalam al-Qur'an) dan qisas (Kejahatan yang menuntut penjatuhan hukuman yang setimpal) hanya membutuhkan 2 (dua) orang laki-laki untuk menjadi saksi sebagaimana dijelaskan dalam hadis Rasulullah SAW sebagai berikut :

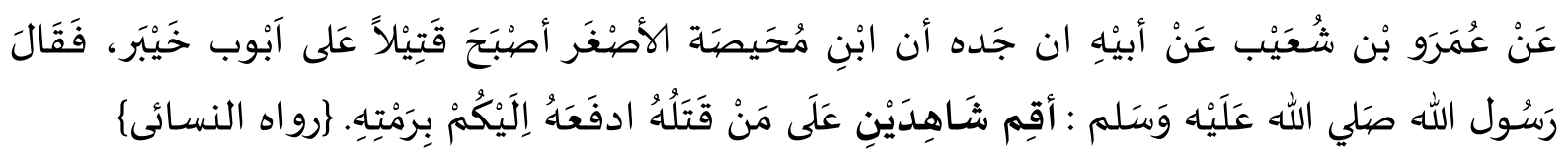

Artinya:

"Dari Amr bin Syua'ib dari ayahnya dari kakeknya mengkhabarkan bahwa Ibn Muhayyisah al-Ashghar menjadi korban pembunuhan di pintu gerbang Khaibar, Rasulullah SAW, memerintahkan kepada walinya : "Kemukakanlah dua orang saksi atas orang yang membunuhnya, nanti kuserahkan seluruhnya (diyat) kepadamu”. \{HR. Nas'i\} ${ }^{13}$

Kedua hadis di atas, menunjukkan bahwa yang menjadi saksi selalu disebutkan lakilaki bukan perempuan yang kemudian menimbulkan pertanyaan apakah perempuan boleh 
menjadi saksi. Menurut sebagian ulama berpendapat bahwa kesaksian perempuan boleh saja diiterima apabila perkara tersebut tidak mungkin disaksikan oleh laki-laki, seperti kasus susuan sebagaimana dijelaskan bahwa Rasulullah SAW pernah menerima kesaksian perempuan pada kasus susuan. Yaitu ketika Uqbah bin al-Harits hendak menikah dengan Umm Yahya binti Abu Lahab, kemudian datanglah seorang hamba sahaya perempuan dan berkata: Saya telah menyusui kalian berdua'. Lalu Uqbah menceritakan perihal tersebut kepada Rasulullah SAW, dan beliau pun membatalkan perkawinan Uqbah dan Umm Yahya.

Oleh karena itu, ulama mazhab Maliki, Syafi'i, dan Hanbali menerima kesaksian perempuan terhadap kasus-kasus yang memang tidak diketahui kaum laki-laki sama sekali seperti berkaitan dengan keperawanan, janda, kelahiran, haid, penyusuan, aib fisik perempuan tertutup baju, dan selesainya iddah.

\section{F. Penutup}

Hukum Islam memiliki kekhususan mengenai kesaksian, yangmana dalam hukum Islam mensyarakat seorang saksi harus bersifat adil berbeda dengan hukum positif yang tidak mensyaratkan adil terhadap para saksi.

Dalam hukum Islam memberikan kesaksian dengan adil atau benar adalah suatu kewajiban bagi setiap kaum Muslim yang dibutuhkan untuk mengemukakan suatu pristiwa hukum guna menegakkan keadilan dan menutup pintu kezaliman.

Banyak sekali kasus-kasus kejahatan yang tidak terungkap dan tidak terselesaikan disebabkan saksi yang takut memberikan keterangan karena mendapatkan ancaman, maka kedepan yang perlu ditekankan adalah bagaimana jaminan perlindungan terhadap saksi dalam perspektif hukum Islam.

\section{End Note :}

${ }^{1}$ Al-Anshari, Lisan al- 'Arab, JUZ VII, (Kairo : DAr al-Mishri, t.th ), hlm. 222.

${ }^{2}$ WJS. Poerwadarminta, Kamus Umum Bahasa Indonesia, ( Jakarta : Balai Pustaka, 1976 ), hlm. 825.

${ }^{3}$ Muhammad Salam Madzkur, al-Qadha' fi al-Islam, ( Kairo : Dar an-Nahḍah al-‘Arabiyah, 1964 ), hlm. 83.

${ }^{4}$ Ibn al-Human, Syarah Fath al-Qadir, juz VII, ( Mesir : Musțhafa al-Bab al-Halabi, 1970 ), hlm. 415.

${ }^{5}$ Mahalli, Qalyubi wa 'Umairah, juz IV, ( Riyad : Maktabah ar-Riyaḍ li al-Hadițah, th ), hlm. 316.

${ }^{6}$ Ibn Hazm, al-Muhalla, jilid 10, ( Mesir : Jumhuriyah al-'Arabiyyah, 1972), hlm. 472.

${ }^{7}$ Imam Muslim, Sahih Muslim bi Syarh an-Nawawi, (Beirut : Dar al-Khair, 1994 ), hlm. 380.

${ }^{8}$ Hendra Gunawan, “Tindak Pidana Penipuan Dalam Perspektif Fikih Jinayah" Pada Jurnal elQanuniy: Jurnal Ilmu-ilmu Kesyari'ahan dan Pranata Sosial Fakultas Syariah dan Ilmu Hukum IAIN Padangsidimpuan, Volume 2 Nomor 2 Edisi Juli-Desember 2018, hlm. 255-268.

${ }_{9}^{9}$ Ibn Hazm, al-Muhalla, hlm. 472.

${ }^{10}$ Muhammad Ibn Isma'il al-Kahlaniy, Subul as-Salam, (Singapura : Sulaiman Mar’iy, 1960), hlm. 126. 
${ }^{11}$ Louis Ma'luf, al-Munjid, ( Beirut : Maktabah asy-Syarqiyyah, 1960 ), hlm. 406.

12 Abu Daud Sulaiman Ibn Asy asy-Sijistani, Sunan Abi Daud, juz IV, ( Suria : Dar al-Hadits, 1973), hlm. 671-672.

${ }^{13}$ Abd Rahman Ahmad bin Su'aib bin Ali al-Khurasani an-Nas'i, Sunan an-Nas'i, julid VIII, (Beirut : Da al-Kitab al-'Ilmiyah, 1995), hlm. 9.

\section{DAFTAR PUSTAKA}

Al-Anshari, Lisan al- 'Arab, juz VII, Kairo: DAr al-Mishri, t.th.

al-Human, Ibn,. Syarah Fath al-Qadir, juz VII, Mesir: Musțhafa al-Bab al-Halabi, 1970.

al-Kahlaniy, Muhammad Ibn Isma'il,. Subul as-Salam, Singapura: Sulaiman Mar'iy, 1960.

an-Nas'i, Abd Rahman Ahmad bin Su'aib bin Ali al-Khurasani,. Sunan an-Nas'i, julid VIII,

Beirut : Da al-Kitab al-'Ilmiyah, 1995.

asy-Sijistani, Abu Daud Sulaiman Ibn Asy,. Sunan Abi Daud, juz IV, Suria: Dar al-Hadits, 1973.

Gunawan, Hendra,. “Tindak Pidana Penipuan Dalam Perspektif Fikih Jinayah” Pada Jurnal el-Qanuniy: Jurnal Ilmu-ilmu Kesyari'ahan dan Pranata Sosial Fakultas Syariah dan Ilmu Hukum IAIN Padangsidimpuan, Volume 2 Nomor 2 Edisi Juli-Desember 2018.

Ibn Hazm, al-Muhalla, jilid 10, Mesir: Jumhuriyah al-'Arabiyyah, 1972.

Ma'luf, Louis,. al-Munjid, Beirut: Maktabah asy-Syarqiyyah, 1960.

Madzkur, Muhammad Salam,. al-Qadha' fi al-Islam, Kairo: Dar an-Naḥḍah al-'Arabiyah, 1964.

Mahalli, Qalyubi wa 'Umairah, juz IV, Riyad: Maktabah ar-Riyaḍ li al-Hadițah, t.th.

Mahalli, Qalyubi wa 'Umairah, juz IV, Riyad: Maktabah ar-Riyaḍ li al-Hadițah, th.

Muslim, Imam,. Sahih Muslim bi Syarh an-Nawawi, Beirut : Dar al-Khair, 1994.

WJS. Poerwadarminta, Kamus Umum Bahasa Indonesia, Jakarta: Balai Pustaka, 1976. 